\title{
INORGANIC RADIOCARBON IN TIME-SERIES SEDIMENT TRAP SAMPLES: IMPLICATION OF SEASONAL VARIATION OF ${ }^{14} \mathrm{C}$ IN THE UPPER OCEAN
}

\author{
MAKIO C. HONDA \\ Japan Marine Science and Technology Center, Ocean Research Department, 2-15 Natsushima, \\ Yokosuka, Kanagawa 237 Japan
}

\begin{abstract}
In order to verify sediment trap samples as indicators of upper ocean ${ }^{14} \mathrm{C}$ concentrations, particulate inorganic radiocarbon (PIC ${ }^{14} \mathrm{C}$ ) collected by time-series sediment traps in the Sea of Okhotsk and the Bering Sea was measured by accelerator mass spectrometry (AMS). All of the PIC $\Delta^{14} \mathrm{C}$ measurements were $<0 \%$, in contrast to GEOSECS ${ }^{14} \mathrm{C}$ data in the upper ocean from the northwestern North Pacific. This difference is attributed to the upwelling of deepwater that contains low $\Delta \Delta^{14} \mathrm{C}$ of dissolved inorganic carbon (DIC $\Delta^{14} \mathrm{C}$ ) and to the decrease over time of surface DIC $\Delta^{14} \mathrm{C}$ owing to the decrease of atmospheric $\Delta{ }^{14} \mathrm{C}$ values. In addition, PIC $\Delta^{14} \mathrm{C}$ values showed significant seasonal variability: PIC ${ }^{14} \mathrm{C}$ collected in the fall was the greatest ( $-22 \%$ on average), whereas PIC $\Delta^{14} \mathrm{C}$ collected in winter showed an average minimum of $-48 \%$. It is likely that this difference was caused by changes in mixed layer thickness. Although some uncertainties remain, further study on $\mathrm{PIC} \Delta{ }^{14} \mathrm{C}$ will enable us to estimate seasonal variability in $\mathrm{DIC} \Delta^{14} \mathrm{C}$ and air-sea $\mathrm{CO}_{2}$ exchange rate.
\end{abstract}

\section{INTRODUCTION}

Radiocarbon is a useful tracer in oceanography. This nuclide has been utilized for studies of ocean circulation (Östlund and Stuiver 1980; Östlund et al. 1987), land-ocean-water interaction (Tanaka, Monaghan and Rye 1986), the tracing of anthropogenic material (Broecker et al. 1985), diets of deep organisms (Williams et al. 1981; Williams, Druffel and Smith 1987; Pearcy and Stuiver 1983), and the origin and age of suspended particle or dissolved organic carbon (Druffel et al. 1992). In addition, ${ }^{14} \mathrm{C}$ can be used in estimating the $\mathrm{CO}_{2}$ exchange rate at the ocean surface. Broecker and Peng (1982) calculated the $\mathrm{CO}_{2}$ invasion rate and estimated the average $\mathrm{CO}_{2}$ exchange rate to be $c a$. $18 \mathrm{~mol} \mathrm{~m}^{-2} \mathrm{yr}^{-1}$ using the atmospheric ${ }^{14} \mathrm{C}$ concentration and a "representative" surface ocean ${ }^{14} \mathrm{C}$ concentration. However, surface $\Delta^{14} \mathrm{C}$ values are variable because of changes in the $\mathrm{CO}_{2}$ exchange rate and in the surface mixed layer thickness, as Broecker and Peng (1980) found when they documented seasonal change in the GEOSECS surface ${ }^{14} \mathrm{C}$ data. Therefore, it is of interest to clarify the seasonal variability of ${ }^{14} \mathrm{C}$ in the surface ocean and to verify the "representative value" (annual mean value) of the ${ }^{14} \mathrm{C}$ concentration in the surface ocean. The time-history and seasonal change of the surface ${ }^{14} \mathrm{C}$ value have been determined from the ${ }^{14} \mathrm{C}$ record of coral reefs (Nozaki et al. 1978; Druffel 1989; Druffel and Linick 1978; Druffel and Suess 1983). However, a coral reef can record DIC $\Delta^{14} \mathrm{C}$ values of the upper ocean only near the coastal zone and at low latitudes $\left(<35^{\circ}\right)$.

Time-series sediment traps deployed in the pelagic ocean have provided us a variety of information, such as the seasonal and annual variability of pelagic ocean productivity and the material cycle (e.g., Honjo and Manganini 1993; Honjo et al. 1995). Most particulate organic carbon and inorganic carbon is assimilated or calcified in the upper ocean by biological activity and is in isotopic equilibrium with the ambient seawater in which it is produced (e.g., Curry, Thunell and Honjo 1983; Curry and Crowley 1987; Rau et al. 1992). Therefore, particulate carbon collected by sediment traps records the DIC $\Delta{ }^{14} \mathrm{C}$ of the upper ocean. Druffel et al. (1986) measured ${ }^{14} \mathrm{C}$ values of a sediment trap sample from the Gulf of Alaska. They showed that PIC ${ }^{14} \mathrm{C}$ agreed with DIC $\Delta{ }^{14} \mathrm{C}$ in the upper ocean. However, they performed only one six-month collection and could not observe seasonal variability in DIC $\Delta{ }^{14} \mathrm{C}$. Since then, there have been few papers devoted to ${ }^{14} \mathrm{C}$ analysis on sediment trap samples because of sample size limitations for beta counting. The development of accelerator mass spectrometry (AMS) (Beukens 1992; Gove 1992) allows us to measure ${ }^{14} \mathrm{C}$ on small samples such as sediment trap samples. In order to verify the possibility of using sediment trap samples as "record- 
ers" of DIC $\Delta^{14} \mathrm{C}$ in the upper ocean and to detect the seasonal variability in $\mathrm{DIC} \Delta^{14} \mathrm{C}$, we measured PIC $\Delta^{14} \mathrm{C}$ in sediment trap samples.

\section{SAMPLING AND ANALYTICAL METHODS}

Sediment trap experiments were carried out in the Sea of Okhotsk (1990-1991) (Honjo et al., in press) and in the Bering Sea (1991-1992) (Honjo et al. ms.). Time-series sediment traps with 21 rotary collectors (Honjo and Doherty 1988) were deployed at $258 \mathrm{~m}$ and $1058 \mathrm{~m}$ water depth in the Sea of Okhotsk and at $3137 \mathrm{~m}$ water depth in the Bering Sea. The trap site in the sea of Okhotsk was covered with sea ice for a short period (1-10 April 1991) (Japan Meteorological Agency 1991) and the Bering Sea trap site was not ice covered (NOAA Sea Ice data produced by Grumbine (1996)). Therefore, the effect of sea ice cover on the biogeochemistry and material exchange at the air-sea boundary can be neglected in this study. Collected materials were preserved with $3 \%$ buffered formalin during one-year experiments.

Three sediment trap samples representing the fall, winter and spring seasons were selected from each sediment trap for this analysis (Table 1, Fig. 1). The winter samples from the Sea of Okhotsk were so small that four interval samples were combined for ${ }^{14} \mathrm{C}$ analysis. Samples $<1 \mathrm{~mm}$ in diameter were filtered, rinsed with distilled water and dried in an oven at $50^{\circ} \mathrm{C}$ for $24 \mathrm{~h}$ in the laboratory at Woods Hole Oceanographic Institution (WHOI). The samples were sequentially pulverized with an agate mortar and pestle. In a vacuum line, the samples were acidified with concentrated $\mathrm{H}_{3} \mathrm{PO}_{4}$ and extracted $\mathrm{CO}_{2}$ was converted to graphite over reduced $\mathrm{Fe}$ catalyst using $\mathrm{H}_{2}$ (McNichol et al. 1992). ${ }^{14} \mathrm{C}$ measurements were performed by the National Ocean Science AMS facility (NOSAMS) at WHOI (Jones et al. 1990; Von Reden et al. 1992). Concentrations of ${ }^{14} \mathrm{C}$ are reported here as $\Delta^{14} \mathrm{C}$, which is the per mil deviation from the activity of 19th century wood (Stuiver and Polach 1977 ) assuming that $\delta^{13} \mathrm{C}$ is $0 \% .10$ counting error is $3-5 \% .{ }^{13} \mathrm{C} /{ }^{12} \mathrm{C}$ was also analyzed using a VG Micromass $602 \mathrm{E}$ mass spectrometer at WHOI. Ratios of ${ }^{13} \mathrm{C} /{ }^{12} \mathrm{C}$ are expressed as $\delta^{13} \mathrm{C}$, which is the

TABLE 1. Total mass flux, chemical composition, and $\Delta^{14} \mathrm{C}$ and $\delta^{13} \mathrm{C}$ values of PIC in sediment trap samples from the Sea of Okhotsk and the Bering Sea. (Errors for carbon isotopes are $1 \sigma$ values of the counting statistics.)

\begin{tabular}{|c|c|c|c|c|c|c|c|c|c|}
\hline Region & $\begin{array}{l}\text { Trap } \\
\text { depth } \\
\text { (m) }\end{array}$ & $\begin{array}{l}\text { Sampling } \\
\text { period }\end{array}$ & $\begin{array}{c}\text { Total } \\
\text { mass } \\
\text { flux (mg/ } \\
\mathrm{m}^{2} / \text { day) }\end{array}$ & $\begin{array}{c}\mathrm{OM}^{*} \\
(\%)\end{array}$ & $\begin{array}{l}\mathrm{SiO}_{2} \\
(\%)\end{array}$ & $\begin{array}{c}\mathrm{CaCO}_{3} \\
(\%)\end{array}$ & $\begin{array}{l}\text { Lith.* } \\
(\%)\end{array}$ & $\begin{array}{l}\Delta^{14} \mathrm{C} \\
(\% 0)\end{array}$ & $\begin{array}{l}\delta^{13} \mathrm{C} \\
(\% 0)\end{array}$ \\
\hline \multirow{2}{*}{$\begin{array}{l}\text { Okhotsk Sea } \\
\left(53^{\circ} \mathrm{N}, 150^{\circ} \mathrm{E}\right) \\
\text { water depth } 1166 \mathrm{~m} \\
\text { Aug } 1991 \text { - } \\
\text { Aug } 1991\end{array}$} & 258 & $\begin{array}{l}09 / 16 / 90-10 / 03 / 90 \mathrm{~F} \dagger \\
12 / 29 / 90-03 / 09 / 91 \mathrm{~W} \\
05 / 17 / 91-06 / 03 / 91 \mathrm{~S}\end{array}$ & $\begin{array}{r}117 \\
10 \\
426\end{array}$ & $\begin{array}{c}36 \\
\text { n.d. } \\
13\end{array}$ & $\begin{array}{l}25 \\
\text { n.d. } \\
80\end{array}$ & $\begin{array}{r}37 \\
\text { n.d. } \\
6\end{array}$ & $\begin{array}{r}2 \\
\text { n.d. } \\
1\end{array}$ & $\begin{array}{l}-25 \pm 3 \\
-12 \pm 3 \\
-39 \pm 4\end{array}$ & $\begin{array}{r}0.02 \pm 0.10 \\
0.43 \pm 0.10 \\
-0.20+0.10\end{array}$ \\
\hline & 1058 & $\begin{array}{l}09 / 16 / 90-10 / 03 / 90 \mathrm{~F} \\
12 / 29 / 90-03 / 09 / 91 \mathrm{~W} \\
05 / 17 / 91-06 / 03 / 91 \mathrm{~S}\end{array}$ & $\begin{array}{r}208 \\
34 \\
296\end{array}$ & $\begin{array}{l}12 \\
18 \\
11\end{array}$ & $\begin{array}{l}33 \\
44 \\
79\end{array}$ & $\begin{array}{r}49 \\
19 \\
6\end{array}$ & $\begin{array}{r}6 \\
19 \\
4\end{array}$ & $\begin{array}{l}-21 \pm 4 \\
-48 \pm 5 \\
-31 \pm 5\end{array}$ & $\begin{array}{r}0.14 \pm 0.10 \\
-0.35 \pm 0.10 \\
-0.11 \pm 0.10\end{array}$ \\
\hline $\begin{array}{c}\text { Bering Sea } \\
\left(58^{\circ} \mathrm{N}, 179^{\circ} \mathrm{E}\right) \\
\text { water depth } 3783 \mathrm{~m} \\
\text { Jul 1991-Jul } 1992\end{array}$ & 3137 & $\begin{array}{l}10 / 13 / 91-10 / 31 / 92 \mathrm{~F} \\
02 / 12 / 92-02 / 29 / 92 \mathrm{~W} \\
06 / 13 / 92-06 / 30 / 92 \mathrm{~S}\end{array}$ & $\begin{array}{r}198 \\
55 \\
1008\end{array}$ & $\begin{array}{l}11 \\
13 \\
11\end{array}$ & $\begin{array}{l}48 \\
49 \\
78\end{array}$ & $\begin{array}{r}26 \\
13 \\
3\end{array}$ & $\begin{array}{r}15 \\
25 \\
8\end{array}$ & $\begin{array}{l}-21 \pm 4 \\
-48 \pm 4 \\
-60 \pm 4\end{array}$ & $\begin{array}{r}0.21 \pm 0.10 \\
0.49 \pm 0.10 \\
-0.71 \pm 0.10\end{array}$ \\
\hline
\end{tabular}

*OM = organic matter; Lith. = lithogenic material

$\dagger \mathrm{F}, \mathrm{W}, \mathrm{S}=$ sample represents fall, winter or spring, respectively

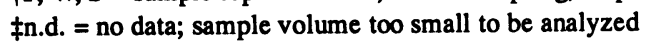


per mil difference in the isotopic ratio between the sample and the PDB standard. $1 \sigma$ counting error is $c a .0 .1 \%$.

\section{RESULTS}

Figure 1 shows seasonal variability in total mass flux and the chemical composition of sediment trap samples (Honjo et al. in press; ms.). The material flux is characterized as follows:

1. Total mass flux in both regions increased in late fall and in late spring.

2. In the Sea of Okhotsk, the fraction of carbonate increased in the fall season, whereas that of $\mathrm{SiO}_{2}$ increased in the spring season.

3. In the Bering Sea, the proportion of $\mathrm{SiO}_{2}$ was dominant all year around, especially in the late spring when total mass flux was $>1000 \mathrm{mg} \mathrm{m}^{-2}$ day $^{-1}$.

4. The fraction of lithogenic materials was $<25 \%$.

$\Delta^{14} \mathrm{C}$ values of sediment trap PIC samples are shown in Table 1 and Figure 2 with other sediment data. All $\Delta^{14} \mathrm{C}$ values are negative. $\Delta^{14} \mathrm{C}$ of the winter sample collected at $258 \mathrm{~m}$ in the Sea of Okhotsk shows the maximum value of $-12 \%$, and the minimum value $(-60 \%)$ is that of the spring sample collected at $3137 \mathrm{~m}$ in the Bering Sea. It is notable that the mass flux of the former was the smallest and the latter was the largest among the samples used for ${ }^{14} \mathrm{C}$ analysis (Fig. 1, Table 1). $\Delta{ }^{14} \mathrm{C}$ values of samples collected in the same season (3 samples in fall, 2 samples in winter and 2 samples in spring) are equal within the measurement uncertainty, except the $\Delta^{14} \mathrm{C}$ of the winter sample $(258 \mathrm{~m})$ from the Sea of Okhotsk and that of the spring sample from the Bering Sea. The PIC $\Delta^{14} \mathrm{C}$ value in fall is the highest $\left(-22 \% 0\right.$ on average) and PIC $\Delta^{14} \mathrm{C}$ value in winter is the lowest ( $-48 \%$ on average). The average of PIC $\Delta^{14} \mathrm{C}$ from 7 samples is $-33 \%$ and the difference of PIC $\Delta^{14} \mathrm{C}$ between fall and spring is $26 \%$. PIC $\Delta^{14} \mathrm{C}$ does not correlate well with total mass flux or organic carbon $(r<0.6)$. However, a plot of PIC $\Delta^{14} \mathrm{C} v$ s. PIC ${ }^{13} \mathrm{C}$ shows good correlation after eliminating one sample $\left(\delta^{13} \mathrm{C}=0.02 \Delta^{14} \mathrm{C}+0.62, r=0.99\right.$ ) (Fig. $3 \mathrm{~A}$ ). In addition, $\mathrm{PIC} \Delta^{14} \mathrm{C}$ and the ratio of the lithogenic material's concentration to total carbonate concentration $\left(\mathrm{Lith} / \mathrm{CaCO}_{3}\right)$ correlate well $(r=0.8)$, as shown in Figure 3B.

\section{Discussion}

\section{Do the Negative PIC $\Delta{ }^{14} \mathrm{C}$ Values Found in This Study Reflect DIC $\Delta{ }^{14} \mathrm{C}$ in the Upper Ocean or Do They Reflect Some Other Low $\Delta^{14} \mathrm{C}$ Carbon Source?}

\section{Formalin Effect}

We did not measure DIC $\Delta{ }^{14} \mathrm{C}$ in the Bering Sea and the Sea of Okhotsk in the early 1990 s. However, the $\Delta^{14} \mathrm{C}$ values found in our sediment trap sample are much lower than the $\Delta^{14} \mathrm{C}$ values in surface water in the northeastern North Pacific obtained by the GEOSECS Pacific expedition in the early 1970s (Östlund and Stuiver 1980). PIC $\Delta^{14} \mathrm{C}$ values are also lower than the mean DIC $\Delta^{14} \mathrm{C}$ in the upper $100 \mathrm{~m}$ from the northwestern North Pacific in the early $1980 \mathrm{~s}$ (ca. 35\%o in April 1983 at $45^{\circ} \mathrm{N}$, $160^{\circ} \mathrm{E}$; Tsunogai et al. 1995). One reason for such low values might be contamination of samples with formalin used as a preservative during the experiment. Formalin is made of petroleum, i.e., from "dead" carbon $\left(\Delta^{14} \mathrm{C}=-1000 \%\right)$. In addition, $\delta^{13} \mathrm{C}$ of formalin is -30 to $-40 \%$ - lower than that of living marine organisms (Fry, personal communication). Some previous reports documented that formalin decreased $\delta^{13} \mathrm{C}$ of organic carbon by a few parts per mil (Mullin, Rau and Eppley 1984; Manganini et al. 1994; Lindsey, Minagawa and Kawaguchi 1995). 


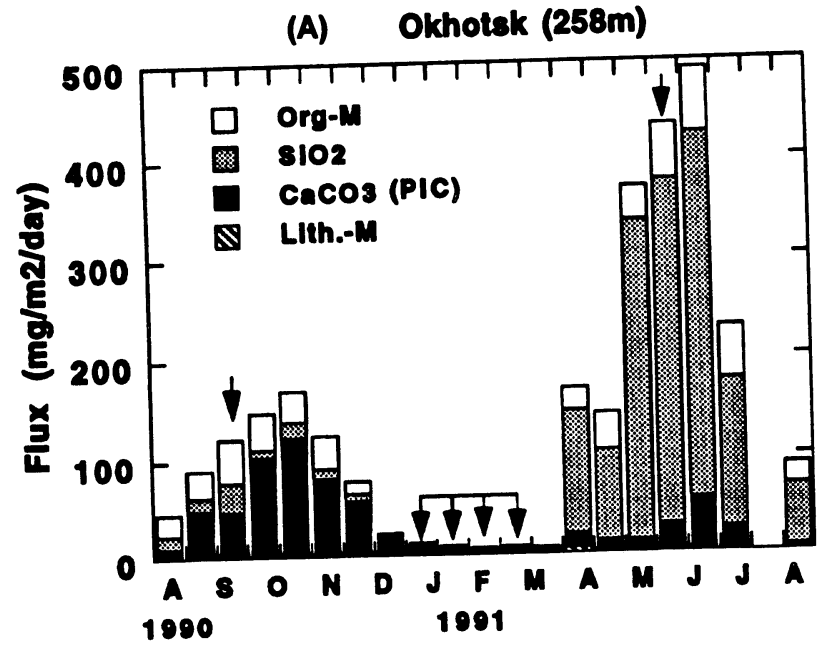

(B) Okhotsk (1058m)
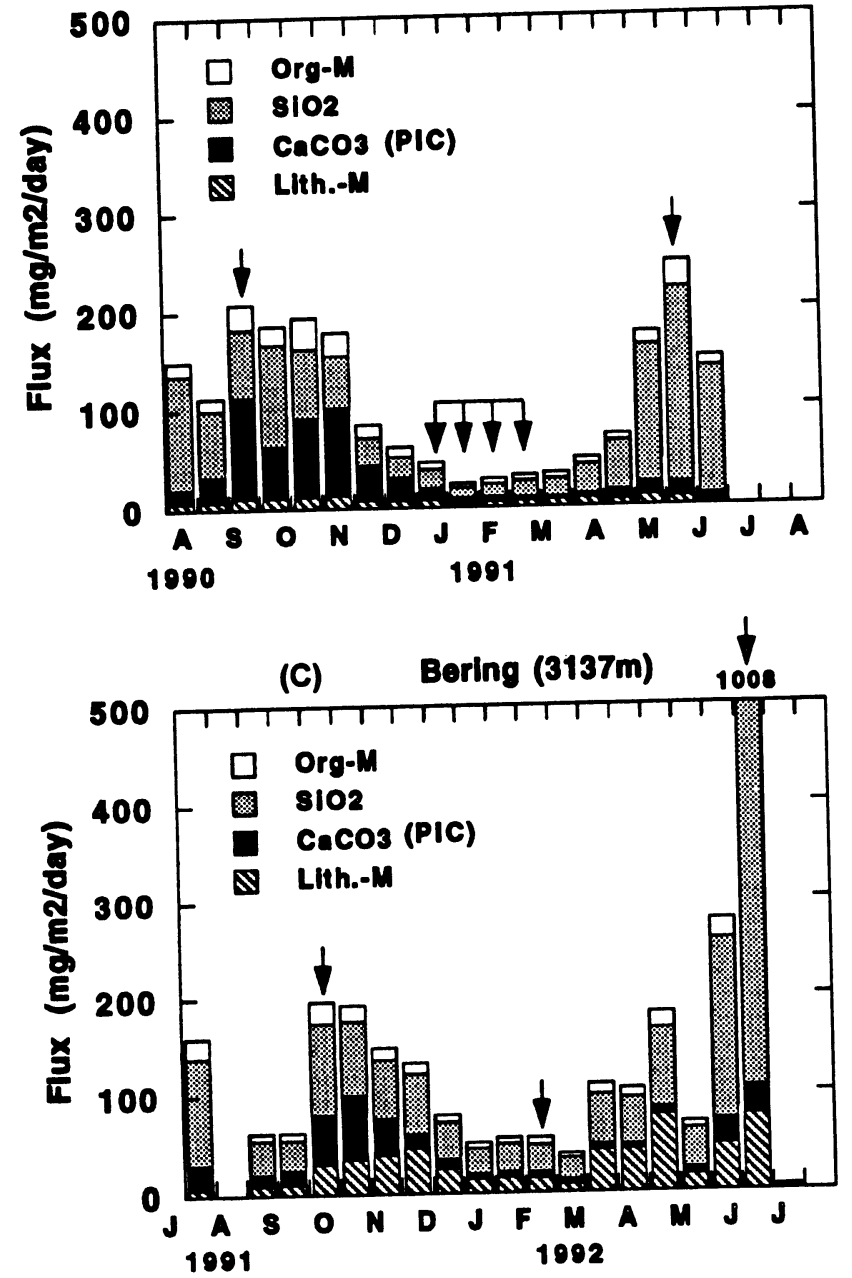

Fig. 1. Seasonal variability in total mass flux and chemical composition of sediment trap samples from: (A) the Sea of Okhotsk (258 m); (B) the Sea of Okhotsk (1058 m); and (C) the Bering Sea $(3137 \mathrm{~m})$. Arrows show samples used for $\mathrm{PIC}^{14} \mathrm{C}$ analysis in this study. 


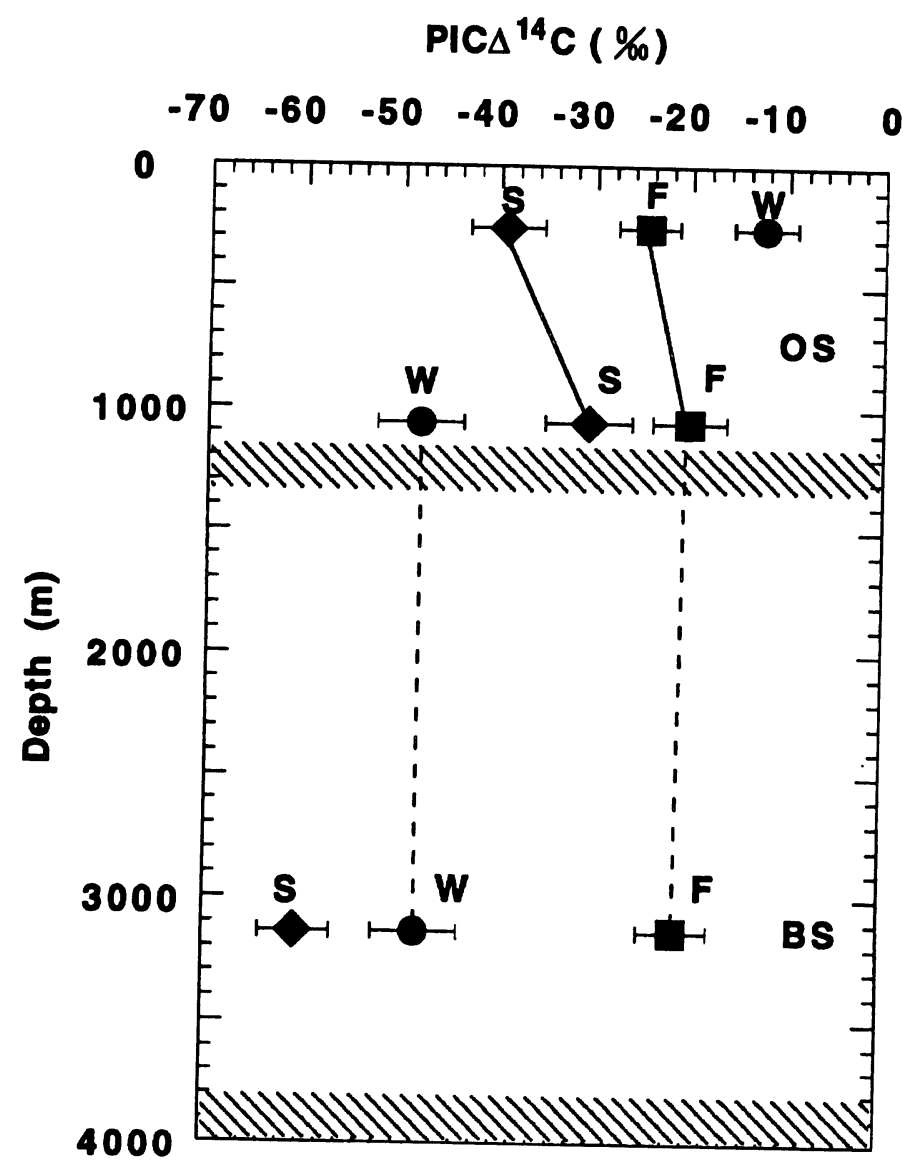

Fig 2. Vertical profile of PIC ${ }^{14} \mathrm{C}$ of sediment trap sample from the Sea of Okhotsk (OS) and Bering Sea (BS). Letters $\mathrm{W}, \mathrm{S}$ and $\mathrm{F}$ indicate PIC ${ }^{14} \mathrm{C}$ of samples collected in winter, spring and fall, respectively. Hatched areas indicate the sea floors for each area.

On the other hand, there have been few reports on the effect of formalin on inorganic carbon isotope values. From stoichiometry, formalin should not bind to inorganic carbon, and it is unlikely that $\mathrm{CO}_{2}$ is extracted from organic carbon in our samples during acidification for ${ }^{14} \mathrm{C}$ analysis. In addition, the relation between $\Delta^{14} \mathrm{C}$ and $8^{13} \mathrm{C}$ observed on our sediment trap samples cannot be explained as a result of formalin. Assuming that (1) the $\Delta^{14} \mathrm{C}$ value and $\delta^{13} \mathrm{C}$ value of formalin were: $-1000 \%$ and -30 to $-40 \%$, respectively; (2) initial (not contaminated) PIC $\Delta^{14} \mathrm{C}$ and $\mathrm{PIC}{ }^{13} \mathrm{C}$ for all samples were $0 \%$ and $0.6 \%$, respectively; and (3) both carbon isotopes change with the degree of contamination by formalin, i.e., with the proportion of formalin-carbon to total PIC, then the observed relation between the two carbon isotopes should be in the hatched area in Figure 4. Figure 4 also shows PIC $\Delta^{14} \mathrm{C}$ and PIC ${ }^{13} \mathrm{C}$, and DIC $\Delta^{14} \mathrm{C}$ and DIC $\delta^{13} \mathrm{C}$ at the GEOSECS Bering Sea station (Stn. G219: $53.6^{\circ} \mathrm{N}, 177.2^{\circ} \mathrm{E}$ ) observed in October 1973. The trend between PIC $\Delta^{14} \mathrm{C}$ and $\mathrm{PIC} \delta^{13} \mathrm{C}$ corresponds well to that between DIC $\Delta^{14} \mathrm{C}$ and $\mathrm{DIC} \delta^{13} \mathrm{C}$, in contrast to the trend caused by formalin. Although the absolute $\delta^{13} \mathrm{C}$ values between sea ater and the sediment trap samples differ, this can be explained by the biological fractionation effect between them reported previously $\left(\delta^{13} \mathrm{C}\right.$ of planktonic foraminifera test such as $G$. bulloides and $N$. pachyderm is ca. 1\%o lower than that of seawater; Kahn and Williams 1981). Based on these considerations, the effect of formalin on PIC $\Delta^{14} \mathrm{C}$ and $\mathrm{PIC} \delta^{13} \mathrm{C}$ is not significant in this study. 


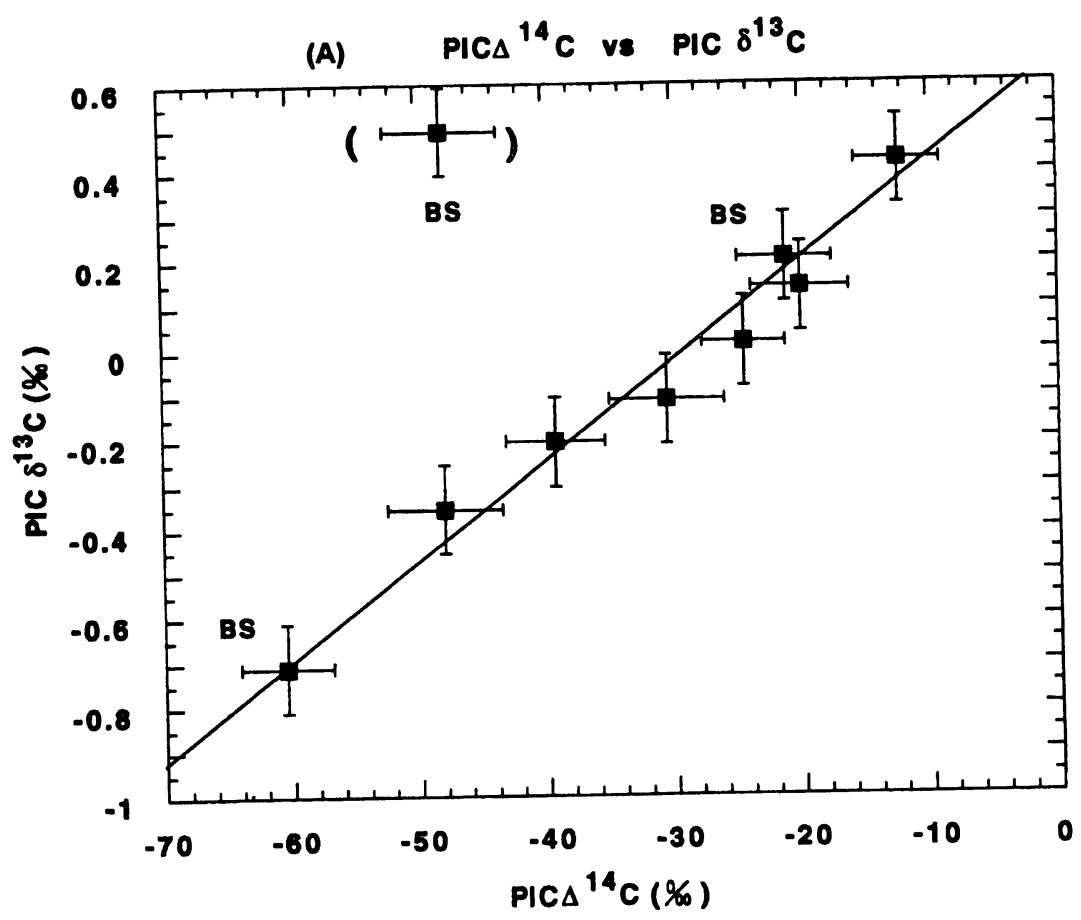

(B) PIC $\Delta^{14} \mathrm{C}$ vs Lith CaCO3

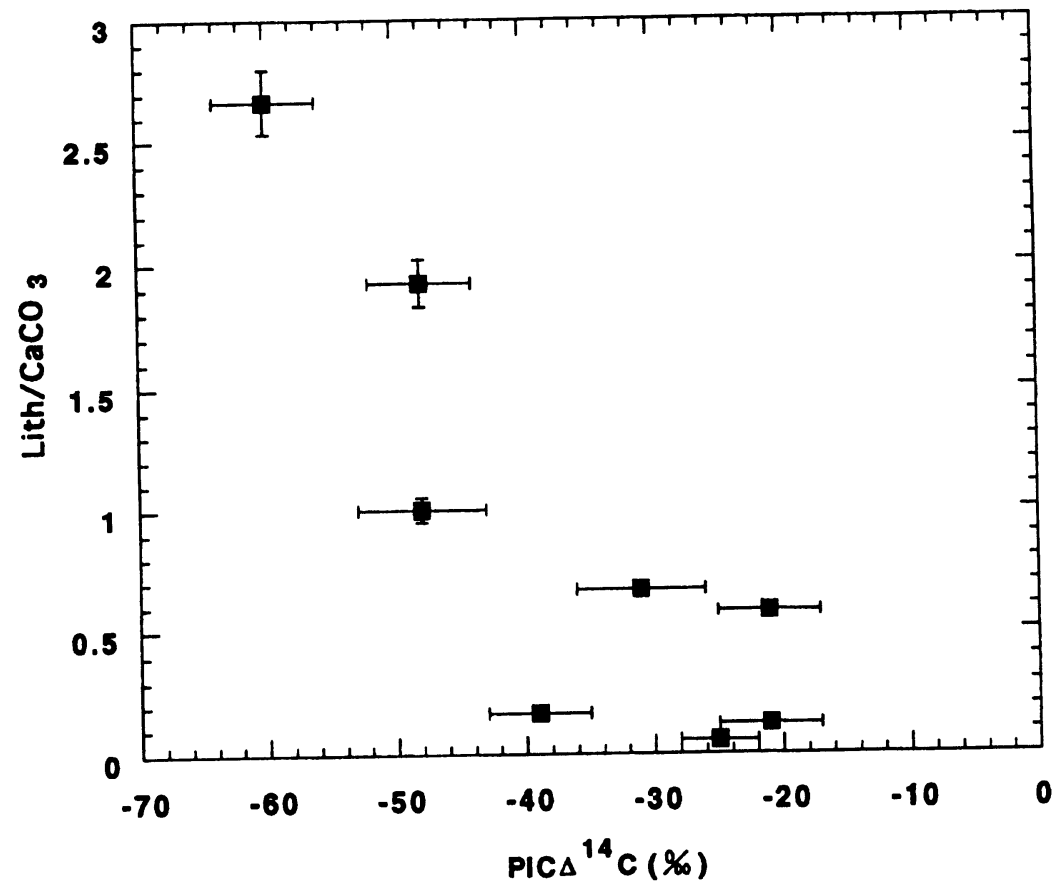

Fig. 3. Relation between (A) PIC $\Delta^{14} \mathrm{C}$ and $\mathrm{PIC}{ }^{13} \mathrm{C}$ and (B) $\mathrm{PIC} \Delta{ }^{14} \mathrm{C}$ and ratio of concentration of lithogenic materials to total carbonate concentration $\left(\mathrm{Lith} / \mathrm{CaCO}_{3}\right)$ 


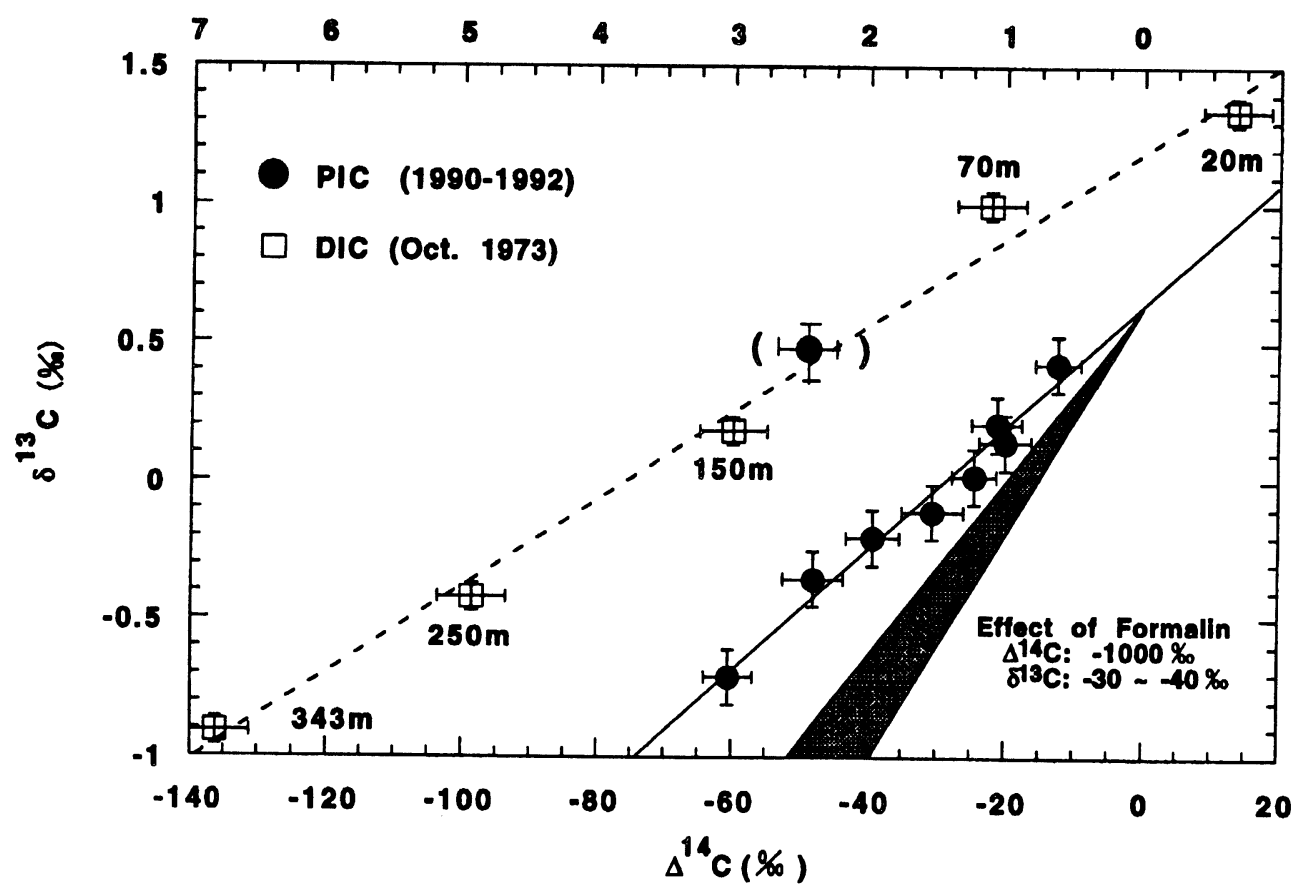

Fig. 4. DIC ${ }^{14} \mathrm{C}$ and $\operatorname{DICS}^{13} \mathrm{C}(\square)$ in the Bering Sea station G219 in October 1973 (Östlund and Stuiver 1980). $-=\mathrm{PIC} \Delta{ }^{14} \mathrm{C}$ and PIC $\delta^{13} \mathrm{C}$. If initial values of PIC $\Delta^{14} \mathrm{C}$ and $\mathrm{PIC}{ }^{13} \mathrm{C}$ for all samples are $0 \% 0$ and $0.62 \%$, respectively, and samples were significantly contaminated by formalin with a low $\Delta^{14} \mathrm{C}$ value of $-1000 \%$ and a low $\delta^{13} \mathrm{C}$ value of -30 to $-40 \%$, PIC $\Delta^{14} \mathrm{C}$ and PIC ${ }^{13} \mathrm{C}$ values should change within the hatched area.

\section{Ocean Surface $\Delta^{14} \mathrm{C}$ in the Bering Sea and the Sea of Okhotsk}

The GEOSECS $\Delta^{14} \mathrm{C}$ data in the northwestern North Pacific were obtained in the early 1970 s (Östlund and Stuiver 1980). As a whole, upper ocean $\Delta{ }^{14} \mathrm{C}$ values in the northern North Pacific and the Equatorial zone are lower than those of other areas because subsurface water upwelling with low $\Delta^{14} \mathrm{C}$ dilutes $\Delta^{14} \mathrm{C}$ in the upper ocean, and bomb-produced ${ }^{14} \mathrm{C}$ is transported laterally to mid-latitudes (Broecker et al. 1985). In particular, the $\Delta^{14} \mathrm{C}$ value of upper water in the Bering Sea is low $\left(+13 \%\right.$ at $20 \mathrm{~m}$ water depth at Stn. G219) in October 1973 and the mean $\Delta^{14} \mathrm{C}$ value of the upper $100 \mathrm{~m}$ was calculated to be $-5 \%$. Alderman, Honjo and Curry (1996) analyzed species composition and isotopic variability $\left(\delta^{13} \mathrm{C}\right.$ and $\left.\delta^{18} \mathrm{O}\right)$ of planktonic foraminifera in our sediment trap samples from the Sea of Okhotsk. They found that the fractions of N. pachyderma and G. bulloides are 57\% and $31 \%$ of total foraminifera flux, respectively, and that both species calcified between $20 \mathrm{~m}$ and $50 \mathrm{~m}$ water depth. If the remains of inorganic carbon collected in our sediment traps were produced by phytoplankton (cocolithophorids), such as Emiliani huxleyi that lived near the surface in the northwestern North Pacific (Honjo and Okada 1974), PIC ${ }^{14} \mathrm{C}$ values should reflect DIC ${ }^{14} \mathrm{C}$ in this upper layer.

Moreover, when our sediment trap experiments were carried out in the early 1990s, ca. $20 \mathrm{yr}$ had passed since the GEOSECS Pacific expedition. As shown in the coral reef record from Florida (Druffel and Linick 1978; Druffel and Suess 1983) and Pacific corals (Druffel 1987), ${ }^{14} \mathrm{C}$ in the surface ocean has been decreasing at mid-gyre regions since GEOSECS observation. Broecker et al. (1985) assumed that this decreasing trend of $\Delta^{14} \mathrm{C}$ can be applied to all of the ocean, including 
upwelling areas such as the northern North Pacific and the equatorial zone. Using this assumption and extrapolating the decreasing trend, as shown in Figure 5, we estimate surface $\Delta^{14} \mathrm{C}$ values in the Bering Sea and northwestern North Pacific (Table 2). Although estimated $\Delta^{14} \mathrm{C}$ values for the northwestern North Pacific (Stn. G217, G218, G222) do not reach negative values, $\Delta^{14} \mathrm{C}$ for the Bering Sea (G219) is estimated to be $-20 \%$, which is close to our observed values in the fall season ( -21 to $-25 \%)$.

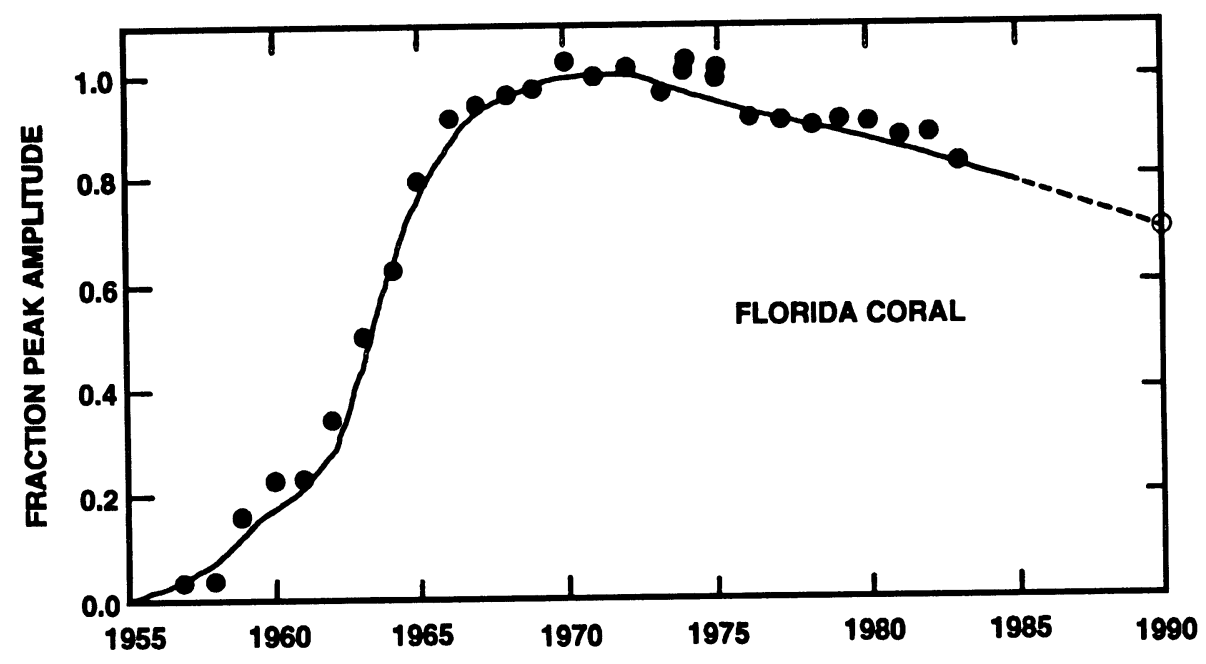

Fig. 5. Shape of $\Delta^{14} \mathrm{C} v s$. time trend adopted for all surface ocean sites (Broecker et al. 1985). It is based on a model run that fits the ring-dated coral results obtained by Druffel and Linick (1978) and Druffel and Suess (1983) for the Florida Straits.

TABLE 2. Time History of DIC ${ }^{14} \mathrm{C}$ of Surface Water in the Northwestern North Pacific Expected with the Time Trend in Figure 5

\begin{tabular}{lccccc}
\hline Year & & 1955 & 1973 & 1985 & 1990 \\
Fraction peak amplitude* & 0.00 & 1.00 & 0.79 & 0.70 \\
\hline & & $\Delta^{14} \mathrm{C}_{(1955)}{ }^{*}$ & $\left.\Delta^{14} \mathrm{C}_{(1973)}\right)^{\dagger}$ & $\left.\Delta^{14} \mathrm{C}_{(1985)}\right)^{\ddagger}$ & $\Delta^{14} \mathrm{C}_{(1990) \ddagger}$ \\
Station & Lat., Long. & $(\% 0)$ & $(\% 0)$ & $(\% 0)$ & $(\% 0)$ \\
\hline G217 & $44.36^{\circ} \mathrm{N}, 176.50^{\circ} \mathrm{W}$ & -80 & 68 & 37 & 24 \\
G218 & $50.26^{\circ} \mathrm{N}, 176.35^{\circ} \mathrm{W}$ & -90 & 63 & 31 & 17 \\
G219 (Bering Sea) & $53.60^{\circ} \mathrm{N}, 177.18^{\circ} \mathrm{W}$ & -100 & 14 & -10 & -20 \\
G222 & $40.10^{\circ} \mathrm{N}, 160.30^{\circ} \mathrm{W}$ & -70 & 84 & 52 & 38 \\
\hline
\end{tabular}

*Broecker et al. (1985)

†Östlund and Stuiver (1980)

$\ddagger \Delta^{14} C_{\text {(year) }}=\left(\Delta^{14} C_{(1973)}-\Delta^{14} C_{(1955)}\right) \times F P A_{\text {(year) }}+\Delta^{14} C_{(1955)}$

There is no DIC $\Delta^{14} \mathrm{C}$ data for the Sea of Okhotsk. However, $\Delta^{14} \mathrm{C}$ for the pre-bomb period recorded in bivalve shells from the surface of the Sea of Okhotsk and the Bering Sea were both ca. $-110 \%$, (J. Southon, personal communication 1996). This indicates that both regions have similar ocean structure and DIC $\Delta^{14} \mathrm{C}$, and that the time histories of $\Delta^{14} \mathrm{C}$ in both oceans after nuclear testing are also similar. Therefore, it is likely that the $\Delta^{14} \mathrm{C}$ values of the sediment trap samples reflect DIC $\Delta^{14} \mathrm{C}$ 
of the upper ocean in the Bering Sea and the Sea of Okhotsk, and that $\Delta^{14} \mathrm{C}$ values in the upper ocean in both areas were negative in the early 1990 s.

\section{What Causes the Seasonal Variability in Surface ${ }^{14} \mathrm{C}$ ?}

As mentioned above, PIC $\Delta^{14} \mathrm{C}$ values showed significant seasonal variation: high $\mathrm{PIC}{ }^{14} \mathrm{C}$ in fall and low PIC $\Delta^{14} \mathrm{C}$ in winter, with a difference of $c a$. 30\%. What causes this seasonal variability in PIC $\Delta^{14} \mathrm{C}$ (or DIC $\Delta^{14} \mathrm{C}$ )?

Biological activity in the upper ocean changes seasonally, as results of sediment trap experiments show, becoming higher in spring and summer than in winter. When organic carbon is assimilated in and removed from the upper ocean, the lighter stable carbon isotope $\left({ }^{12} \mathrm{C}\right)$ is used preferentially and both $8^{13} \mathrm{C}$ and $\Delta^{14} \mathrm{C}$ of seawater should become higher. However, DIC $\Delta^{14} \mathrm{C}$ does not change, because it is corrected for isotope fractionation. The $\mathrm{CO}_{2}$ exchange rate at the air-sea boundary also changes seasonally. The faster the $\mathrm{CO}_{2}$ exchange rate, the greater the increase in $\Delta^{14} \mathrm{C}$ of surface seawater, because atmospheric $\Delta^{14} \mathrm{C}$ is higher than that of surface seawater (e.g., Nydal and Lovseth 1983). In general, the $\mathrm{CO}_{2}$ exchange rate could increase in winter because it is said to be winddependent (Tans, Fung and Takahashi 1990). If the $\mathrm{CO}_{2}$ exchange rate affected $\Delta^{14} \mathrm{C}$ of surface seawater significantly, $\Delta^{14} \mathrm{C}$ of surface seawater could be higher in winter than in fall. However, the observed change in DIC $\Delta^{14} \mathrm{C}$ is completely opposite to this. It is, therefore, unlikely that the above two phenomena change $\mathrm{DIC} \Delta^{14} \mathrm{C}$ of the upper ocean significantly.

Another possibility is the change in mixed layer thickness. Dodimead (1967) reported that the thickness of the winter mixed layer reached ca. $150 \mathrm{~m}$ in the northwestern North Pacific (subarctic zone). In the case of the Sea of Okhotsk, the thickness of the winter mixed layer should be, at most, $150 \mathrm{~m}$, because of the existence of a dichothermal layer (cold halocline; Kitani (1973)). Assuming that the upper ocean is stratified in the fall season and that the upper $150 \mathrm{~m}$ is well mixed in winter, we calculated the difference between $\Delta^{14} \mathrm{C}$ values in summer and winter using GEOSECS $\Delta^{14} \mathrm{C}$ data at the Bering Stn. G219 (Östlund and Stuiver 1980). As shown in Figure 6, the mean values of $\Delta^{14} \mathrm{C}$ for each layer of $0-50 \mathrm{~m}, 50-100 \mathrm{~m}$ and $100-150 \mathrm{~m}$ were $+3,-22$ and $-60 \%$, respectively. Assuming that there is no $\mathrm{CO}_{2}$ exchange at two boundaries (the atmosphere / the upper layer and the lower layer / water mass below $150 \mathrm{~m}$ ) and total dissolved carbon $\left(\Sigma \mathrm{CO}_{2}\right)$ for each layer is the same, $\Delta^{14} \mathrm{C}$ of the mixed layer of $150 \mathrm{~m}$ in the winter can be estimated to be $-26 \%$ (Fig. 6). The difference of $\Delta{ }^{14} \mathrm{C}$ in the upper $50 \mathrm{~m}$ between summer and winter is $29 \%$, which is approximately coincident with the difference between fall values and winter values observed in our sediment trap samples (26\%). Therefore, it can be concluded that much of the observed difference in $\Delta^{14} \mathrm{C}$ is attributable to the change of surface mixed layer thickness.

However, it is still difficult to explain the maximum and minimum $\Delta^{14} \mathrm{C}$ values. The maximum value of $\Delta^{14} \mathrm{C}(-12 \%)$ is obtained from the winter sample in the Okhotsk shallow sediment trap, and the total mass flux of this sample is quite small. At least two processes could increase the $\Delta^{14} \mathrm{C}$ values: 1) contamination of air with high $\Delta^{14} \mathrm{C}$ during sample preparation or analysis and; 2) "fresh" terrestrial material input. Because of the relatively small volume, these processes might affect PIC $\triangle{ }^{14} \mathrm{C}$ significantly.

On the other hand, the minimum value (-60\%) is obtained from the Bering spring sample, which is the largest mass flux among the sample set due to the spring bloom. One possibility is input of old resuspended sea-floor sediment. We used the bulk carbonate for $\Delta^{14} \mathrm{C}$ analysis. Although we assume that this carbonate consisted of tests of cocolithophorids and foraminifera living in the upper ocean, old terrestrial inorganic carbon might be included. Negative $\Delta^{14} \mathrm{C}$ values observed recently in sediment trap samples from other locations were attributed to the input of old terrestrial material or sea- 


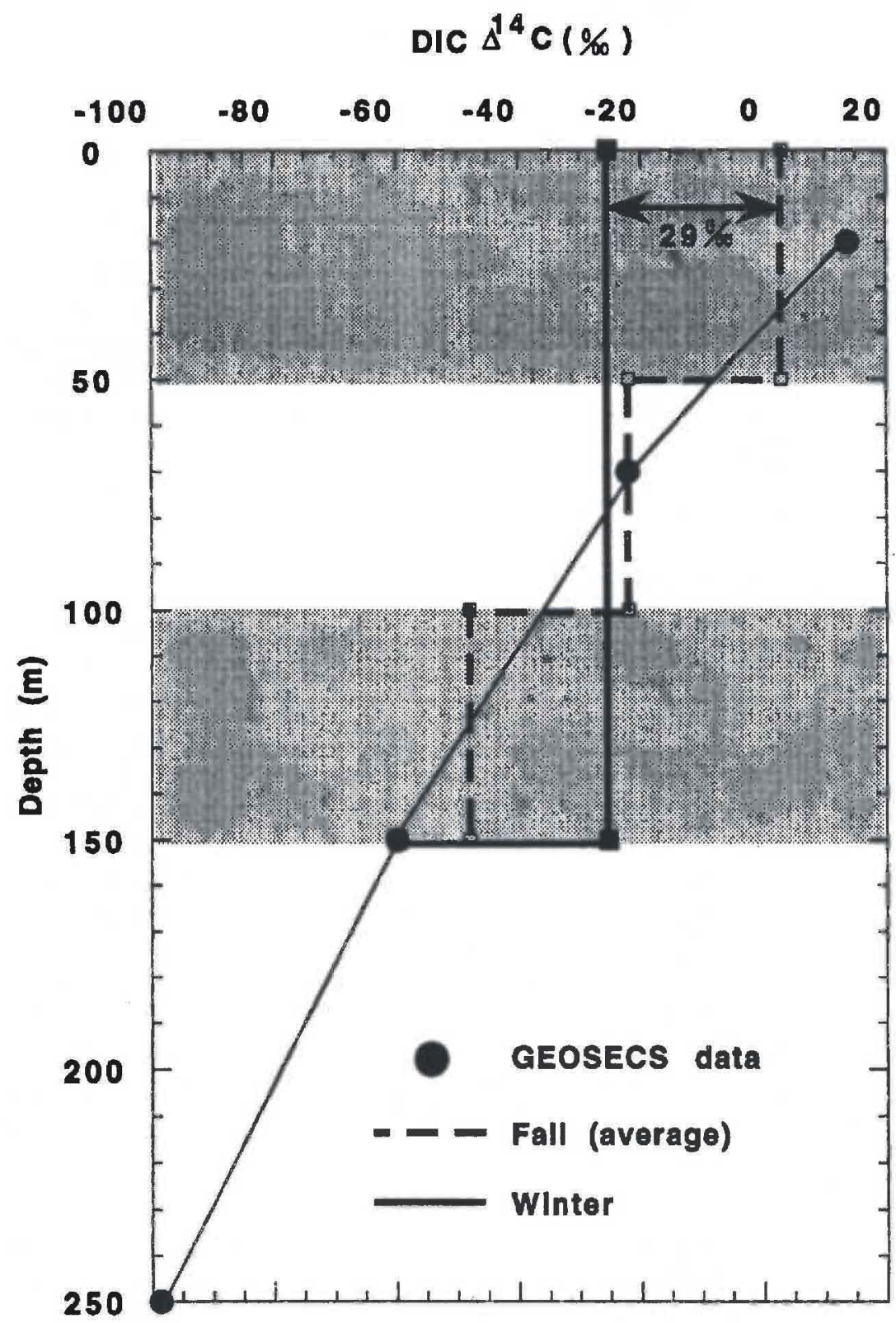

Fig. 6. Expected seasonal change in DIC $\Delta^{14} \mathrm{C}$ in the upper ocean. DIC $\Delta^{14} \mathrm{C}$ values are obtained from GEOSECS data (Östlund et al. 1987). The change in DIC ${ }^{14} \mathrm{C}$ between fall and winter is calculated to be $29 \%$.

floor sediment resuspended on the deep-sea floor (Anderson et al. 1994; Nakatsuka 1995). In the case of the Bering spring sample, the $\mathrm{Lith} / \mathrm{CaCO}_{3}$ ratio was the highest among sediment-trap samples used in this study (Table 1). If lithogenic materials collected by the sediment trap were derived from sea-floor sediment, and the carbonate concentration in sea-floor sediment was $5 \%, c a .13 \%$ of the total carbonate collected by sediment trap could be that of sea-floor sediment. Assuming that 
$\Delta^{14} \mathrm{C}$ of carbonate without sea-floor carbonate is $-35 \%$, which is the average PIC $\Delta^{14} \mathrm{C}$ of the Okhotsk spring samples, the $\Delta^{14} \mathrm{C}$ of sea-floor carbonate is estimated to be $-227 \%$. Walsh $e$ al al. (1985) measured $\Delta^{14} \mathrm{C}$ of carbonate in sea-floor sediment on the shelf $(390 \mathrm{~m})$ and slope $(1500 \mathrm{~m})$ in the Bering Sea. The $\Delta^{14} \mathrm{C}$ of carbonate in surface sediments (upper $20 \mathrm{~cm}$ ) on the shelf and slope were ca. $-400 \%$ and $-160 \%$, respectively. Estimated $\Delta^{14} \mathrm{C}(-227 \%)$ is thus within the range observed by Walsh et al. (1985). The good correlation between PIC $\Delta{ }^{14} \mathrm{C}$ and $\mathrm{Lith} / \mathrm{CaCO}_{3}$ can be seen in Figure 3B. Although the carbonate concentrations and $\Delta^{14} \mathrm{C}$ values in sea-floor sediment are unknown, good correlation between them might mean that the higher the contribution of carbonate in lithogenic material to total carbonate collected by sediment traps, the lower the PIC $\Delta^{14} \mathrm{C}$. It is, therefore, likely that the lower values are attributed to the presence of a resuspended carbonate component in the trap material, and it is possible that resuspended carbonate affects PIC $\Delta^{14} \mathrm{C}$ slightly.

\section{Conclusion}

Particulate inorganic ${ }^{14} \mathrm{C}$ in sediment trap samples from the Sea of Okhotsk and the Bering Sea were analyzed by NOSAMS. $\Delta^{14} \mathrm{C}$ showed negative values and varied seasonally. It is likely that these results are principally due to the decrease of bomb-produced ${ }^{14} \mathrm{C}$ concentration in the ocean surface since the GEOSECS period, and the seasonal changes in mixing layer thickness, respectively. Timeseries sediment trap sample data appear to be useful for the determination of DIC $\Delta^{14} \mathrm{C}$ in the upper ocean. However, this trial is just the first step toward applying sediment trap sample $\Delta^{14} \mathrm{C}$ to determine the seasonal variability in mixed layer thickness or $\mathrm{CO}_{2}$ exchange rate. In further experiments, the following procedures are strongly recommended: 1) carbonate of sediment trap samples used for ${ }^{14} \mathrm{C}$ analysis should be well characterized, i.e., only carbonate produced in the upper ocean should be used and; 2) a sediment trap should be deployed just below the euphotic zone, and a conductivity/ temperature/depth probe (CTD) that can observe the conservative quantities such as salinity and temperature should also be deployed to observe the change in ocean structure and detect the change in $\mathrm{DIC} \Delta{ }^{14} \mathrm{C}$ by $\mathrm{CO}_{2}$ exchange.

\section{ACKNOWLEDGMENTS}

I very much appreciate encouragement from Susumu Honjo. Without his support, this study and all of my activity at WHOI could not have been carried out. I thank Steven J. Manganini, and all of the crew of R/V Shoyo in the Sea of Okhotsk and R/V Wakashio and R/V Alpha Helix in the Bering Sea for their enthusiastic assistance with the sediment trap experiment. I am also grateful to Ann P. McNichol and the NOSAMS stuff for ${ }^{14} \mathrm{C}$ analysis. I am deeply indebted to Masashi Kusakabe, John Southon and, especially, Ellen R. M. Druffel for critical readings of the manuscript and suggestions. The ${ }^{14} \mathrm{C}$ measurements at NOSAMS were NSF-supported, by cooperative agreement OCE-801015.

\section{REFERENCES}

Alderman, S. E., Honjo, S. and Curry, W. B. 1996 Seasonal transition of species composition and isotopic variability of planktonic foraminifera in the sea of Okhotsk (Abstract). 1996 AGU Ocean Science Meeting Abstracts 76: OS76.

Anderson, R. F., Rowe, G. T., Kemp, P., Trumbore, S. and Biscaye, P. E. 1994 Carbon budget for the mid-slope depocenter of the Middle Atlantic Bight: A test of the shelf export hypothesis. Deep-Sea Research II 41: 669-703.

Beukens, R. P. 1992 Radiocarbon accelerator mass spec- trometry: Background, precision, and accuracy. In Taylor, R. E., Long, A. and Kra, R. S., eds. Radiocarbon After Four Decades: An Interdisciplinary Perspective. New York, Springer-Verlag: 230-240.

Broecker, W. S. and Peng, T. H. 1980 Seasonal variability in the ${ }^{14} \mathrm{C} /{ }^{12} \mathrm{C}$ ratio for surface ocean water. Geophysical Research Letters 7: 1020-1022.

1982 Tracers in the Sea. Palisades, New York, Eldigio Press: $690 \mathrm{p}$.

Broecker, W. S., Peng, T. H., Östlund, G. and Stuiver, M. 1985 The distribution of bomb radiocarbon in the 
ocean. Journal of Geophysical Research 90: 69536970.

Curry, W. B. and Crowley T. J. $1987 \delta^{13} \mathrm{C}$ in equatorial Atlantic surface waters: Implications for the Ice Age $\mathrm{pCO}_{2}$ levels. Paleoceanography 2: 489-517.

Curry, W. B., Thunell, R. C. and Honjo, S. 1983 Seasonal changes in the isotopic composition of planktonic foraminifera collected in Panama Basin sediment traps. Earth and Planetary Science Letters 64: 33-44.

Dodimead, A. J. 1967 Winter oceanographic conditions in the central Subarctic Pacific. International North Pacific Commerce Document 999: 14.

Druffel, E. R. M. 1987 Bomb radiocarbon in the Pacific annual and seasonal time scale variations. Journal of Marine Research 45: 667-698.

1989 Variability of ventilation in the North Atlantic determined from high precision measurements of bomb radiocarbon in banded corals. Journal of $\mathrm{Geo}$ physical Research 94: 3271-3285.

Druffel, E. R. M., Honjo, S., Griffin, S. and Wong, C. S. 1986 Radiocarbon in particulate matter from the Eastern Sub-Arctic Pacific Ocean: Evidence of a source of terrestrial carbon to the deep sea. In Stuiver, M. and Kra, R. S., eds., Proceedings of the 12th International ${ }^{14} \mathrm{C}$ Conference. Radiocarbon 28(2A): 397-407.

Druffel, E. R. M. and Linick, T. W. 1978 Radiocarbon in annual coral rings of Florida. Geophysical Research Letters 5: 913-916.

Druffel, E. R. M. and Suess, H. E. 1983 On the radiocarbon record in banded corals: Exchange parameters and net transport of ${ }^{14} \mathrm{CO}_{2}$ between atmosphere and surface ocean. Journal of Geophysical Research 88(C2): 1271-1280.

Druffel, E. R. M., Williams, P. M., Bauer, J. E. and Ertel, J. R. 1992 Cycling of dissolved and particulate organic matter in the open ocean. Journal of Geophysical Research 97: 15,639-15,659.

Gove, H. E. 1992 The history of AMS, its advantages over decay counting: Applications and prospects. In Taylor, R. E., Long, A. and Kra, R. S., eds., Radiocarbon After Four Decades: An Interdisciplinary Perspective. New York, Springer-Verlag: 214-229.

Grumbine, R. W. 1996 Automated passive microwave sea ice concentration analysis at NCEP. NOAA National Weather Service Technical Note: 1-13.

Honjo, S. et al. ms. in preparation.

Honjo, S. and Doherty, K. 1988 Large aperture time-series sediment traps: Design objectives, construction and application. Deep-Sea Research 35: 133-149.

Honjo, S., Dymond, J., Collier, R. and Manganini, S. J. 1995 Export production of particles to the interior of the equatorial Pacific Ocean during the $1992 \mathrm{EqPac}$ experiment. Deep-Sea Research 42: 831-870.

Honjo, S., Honda, M. C., Manganini, S. J. and Ishii, H., in press, Biogeochemical cycles in the Sea of Okhotsk, a temporary ice-bound large marginal sea. Deep-Sea Research.

Honjo, S. and Manganini, S. J. 1993 Annual biogenic particle fluxes to the interior of the North Atlantic Ocean: Studied at $34^{\circ} \mathrm{N} 21^{\circ} \mathrm{W}$ and $48^{\circ} \mathrm{N} 21^{\circ} \mathrm{W}$. DeepSea Research 40: 587-607.

Honjo, S. and Okada, H. 1974 Community structure of Coccolithophores in the photic layer of the Mid-Pacific. Micropaleoceanography 20: 209-230.

Japan Meteorological Agency 1991 The Results of Sea Ice Observation. Vol. 9. Tokyo, Naigai Press: 41 p.

Jones, G. A., McNichol, A. P., von Reden, R. F. and Schneider, R. J. 1990 The National Ocean Sciences AMS facility at Woods Hole. Nuclear Instruments and Methods in Physics Research 52: 278-284.

Kahn, M. I. and Williams, D. F. 1981 Oxygen and carbon isotopic composition of living planktonic foraminifera from the northeast Pacific Ocean. Paleogeography, Paleoclimatology and Paleoecology 33: 47-76.

Kitani, K. 1973 An oceanographic study of the Okhotsk Sea, particularly in regard to cold waters. Bulletin of Far Seas Fisheries Research Laboratory 9: 45-76.

Lindsey, D., Minagawa, M. and Kawaguchi K. 1995 Problem in sample preservation for stable isotope analysis (Abstract). 1995 Japan Ocean Science Spring Meeting: 334.

Manganini, S. J., Honjo, S., Altabet, M. and Honda, M. C. 1994 The effect of preservatives on settling particles as collected by sediment trap during EqPac experiment (Abstract). American Geophysical Uniom American Societies of Limnology and Oceanography 75(3): 84.

McNichol, A. P., Gagnon, A. R., Jones, G. A. and Osborne, E. A. 1992 Illumination of a black box: Analysis of gas composition during graphite target preparation. In Long, A. and Kra, R. S., eds., Proceedings of the 14th International ${ }^{14} \mathrm{C}$ Conference. Radiocarbon 34(3): 321-329.

Mullin, M. M., Rau, G. H. and Eppley, R. W. 1984 Stable nitrogen isotopes in zooplankton: Some geographic and temporal variations in the North Pacific. Limnology and Oceanography 29: 1267-1273.

Nakatsuka, T. 1995 Origin and transport of particulate organic matter in deep sea water column of ocean. In "Modern Chemical Oceanography", special issue of Kaiyo Monthly 8: 121-126 (in Japanese).

Nozaki, Y., Rye, D. M., Turekian, K. K. and Dodge, R. E. 1978 C-13 and C-14 variations in a Bermuda coral. Geophysical Research Letters 5: 825-828.

Nydal, R. and Lovseth, K. 1983 Tracing bomb ${ }^{14} \mathrm{C}$ in the atmosphere 1962-1980. Journal of Geophysical Research 88: 3621-3642

Östlund, H. G. and Stuiver, M. 1980 GEOSECS Pacific radiocarbon. Radiocarbon 22(1): 25-53.

Östlund, H. G., Craig, H., Broecker, W. S. and Spencer, D. 1987 GEOSECS Atlantic, Pacific, and Indian Ocean Expeditions. Vol. 7, Shorebased Data and Graphics. Washington, D.C., National Science Foundation: $200 \mathrm{p}$.

Pearcy, W. G. and Stuiver, M. 1983 Vertical transport of carbon-14 into deep-sea food webs. Deep-Sea Re- 
search 30: 427-440.

Rau, G. H., Takahashi, T., DesMarais, D. J., Repeta, D. J. and Martin, J. H. 1992 The relationship between $\delta^{13} \mathrm{C}$ of organic matter and $\left[\mathrm{CO}_{2}(\mathrm{aq})\right]$ in ocean surface water: Data from JGOFS site in the northeast Atlantic Ocean and a model. Geochimica et Cosmochimica Acta 56: 1413-1419.

Stuiver, M. and Polach, H. A. 1977 Discussion: Reporting of ${ }^{14} \mathrm{C}$ data. Radiocarbon 19(3): 355-363.

Tanaka, N., Monaghan, M. C. and Rye, D. M. 1986 Contribution of metabolic carbon to mollusc and barnacle shell carbonate. Nature 320: 520-523.

Tans, P. P., Fung, I. Y. and Takahashi, T. 1990 Observational constraints on the global atmospheric $\mathrm{CO}_{2}$ budget. Science 247: 1431-1438.

Tsunogai, S., Watanabe, S., Honda, M. C. and Aramaki, T. 1995 North Pacific Intermediate Water studied chiefly with radiocarbon. Journal of Oceanographic Society of Japan 51: 519-536.

Von Reden, K. F., Jones, G. A., Schneider, R. J., McNi- chol, A. P., Cohen, G. J. and Purser, K. H. 1992 The new National Ocean Science Accelerator Mass Spectrometer Facility at Woods Hole Oceanographic Institution: Progress and first results. In Long, A. and Kra, R. S., eds., Proceedings of the 14 th International ${ }^{14} \mathrm{C}$ Conference. Radiocarbon 34(3): 478-482.

Walsh, J. J., Premuzic, E. T., Gaffney, J. S., Rowe, G. T., Harbottle, G., Stoenner, R. W., Balsam, W. L., Betzer, P. R. and Macro, S. A. 1985 Organic storage of $\mathrm{CO}_{2}$ on the continental slope off the mid-Atlantic bight, the southeastern Bering Sea, and the Peru coast. Deep-Sea Research 32: 853-883.

Williams, P. M., Smith, K. L., Druffel, E. R. M. and Linick, T. W. 1981 Dietary carbon sources of mussels and tubeworms from Galapagos hydrothermal vents determined from tissue ${ }^{14} \mathrm{C}$ activity. Nature 292: 448-449.

Williams, P. M., Druffel, E. R. M. and Smith, K. L., Jr. 1987 Dietary carbon sources for deep-sea organisms as inferred from their organic radiocarbon activities. Deep-Sea Research 34: 253-266. 